\title{
Cemaran Mikroba Escherichia coli dan Total Bakteri Koliform pada Air Minum Isi Ulang
}

\section{Escherichia coli Microbial and Total Coliform Bacterial Contamination of Refill Drinking Water}

\author{
Rolan Sudirman Pakpahan*, Intje Picauly*, I Nyoman Widiarta Mahayasa**
}

\author{
* Program Studi Ilmu Kesehatan Masyarakat Fakultas Kesehatan Masyarakat Universitas Nusa Cendana, \\ **Fakultas Pertanian Universitas Nusa Cendana
}

\begin{abstract}
Abstrak
Jumlah layanan air minum melalui depot air minum di Kota Kupang meningkat dengan rata-rata 1,44 setiap tahun sejak 2010, sementara tidak terdapat jaminan kualitas air minum isi ulang memenuhi syarat setiap saat. Hasil pemeriksaan sampel air minum isi ulang di Kota Kupang tahun 2013 menunjukkan 37,5\% tercemar mikroba. Tujuan penelitian ini adalah menganalisis cemaran mikroba dan mengetahui determinan cemaran Escherichia coli (E. coli) dan total koliform pada air minum isi ulang. Penelitian ini menggunakan desain studi potong lintang periode Januari Maret 2015. Populasi penelitian berjumlah 51 depot air minum yang ditentukan menggunakan teknik total sampling. Analisis data dilakukan secara univariat, analisis bivariat menggunakan uji regresi logistik sederhana, dan analisis multivariat menggunakan regresi logistik berganda. Hasil penelitian terhadap 51 depot air minum menunjukkan air minum telah tercemar mikroba sebanyak 26 depot air minum (51\%), tercemar E. coli 33,33\%, dan tercemar total koliform $51 \%$. Deteminan cemaran mikroba dengan uji bivariat adalah pengetahuan (nilai $p=0,01$ ), sikap operator (nilai $p=0,05$ ). Sedangkan determinan cemaran mikroba uji multivariat adalah pengetahuan operator (nilai $p=0,026$ ), kebersihan operator (nilai $p=0,05$ ) dan sanitasi depot air minum (nilai $p=0,044$ ). Variabel yang paling dominan memengaruhi cemaran mikroba adalah pengetahuan, kebersihan operator, dan sanitasi depot air minum.

Kata kunci: Air minum isi ulang, depot air minum, Escherichia coli, total koliform
\end{abstract}

\section{Abstract}

Amount of drinking water services through drinking water depots in Kupang City is increasing in avarage of 1.44 every year since 2010, meanwhile there is no guarantee that refill drinking water quality meets any requirement every time. Results of refill drinking water sample in Kupang City in 2013 showed the water was $37.5 \%$ contaminated by microbes. This study aimed to analyze microbial contamination and determine determinants of
Escherichia coli (E. coli) and total Coliform on refill drinking water. This study used cross sectional design on January - March 2015. The population was 51 depots determined using total sampling technique. Data analysis was conducted in univariate, bivariate using simple logistic regression test and multivariate using multiple logistic regression test. Results showed drinking water contaminated by microbes worth 26 depots (51\%), by E. coli $33.33 \%$ and by total Coliform $51 \%$. Microbial contamination determinants using bivariate were knowledge ( $p$ value $=0.01$ ) and behavior of operator ( $p$ value $=0.05)$. Meanwhile, microbial contamination determinants conducting multivariate were knowledge ( $p$ value $=0.026$ ), hygiene of operator $(p$ value $=0.05)$ and depot sanitation $(p$ value $=0.044)$. Most dominating variables influencing microbial contamination are knowledge, operator's hygiene and depot sanitation.

Keywords: Refill drinking water, drinking water depot, Escherichia coli, total coliform

\section{Pendahuluan}

Perkembangan teknologi telah membawa kemajuan dalam pelbagai bidang kehidupan, salah satunya di bidang kesehatan, yaitu teknologi pengolahan depot air minum (DAM). Teknologi ini mengubah air bersih menjadi air minum tanpa dimasak terlebih dahulu, namun diolah dengan cara filtrasi dan desinfeksi. ${ }^{1}$ Adanya DAM mempermudah masyarakat dalam penyediaan air minum. Air minum merupakan kebutuhan pokok manusia. Tubuh kita memerlukan air untuk kelangsungan hidup. Kita memerlukan air antara 30 - 60 liter per hari. ${ }^{2}$

Kegunaan air yang sangat penting adalah untuk

Korespondensi: Rolan Sudirman Pakpahan, Program Studi Ilmu Kesehatan Masyarakat Universitas Nusa Cendana, Jl. Adi Sucipto Kupang 85148, No.Telp: 0380-881021,email:rolans_pakpahan@yahoo.com 
minum. Oleh karena itu, air minum harus memenuhi syarat-syarat kesehatan, baik fisik, kimia, radioaktif maupun mikrobiologis agar tidak menimbulkan gangguan kesehatan. Agar air aman dikonsumsi, diperlukan pengolahan air untuk menghilangkan cemaran mikroba atau menurunkan kadar bahan tercemar sesuai standar yang ditetapkan.

Air tercemar disebabkan masuknya atau dimasukkannya zat, energi, dan atau komponen lain ke dalam air oleh kegiatan manusia sehingga kualitas air turun sampai tingkat tertentu yang membahayakan, mengakibatkan air tidak berfungsi lagi sesuai peruntukannya. ${ }^{3}$ Air tersebut hanya dapat digunakan untuk tujuan lain yang tidak berisiko terhadap makhluk hidup. Masuknya bahan pencemar ke dalam air berbeda. Pada cemaran mikroba, mekanisme penyebarannya dari tinja ke air minum melalui air, tangan, vektor, dan tanah. ${ }^{2}$

Indikator pencemaran mikroba air minum adalah total koliform dan Escherichia coli (E. coli). Total koliform adalah suatu kelompok bakteri yang digunakan sebagai indikator adanya polusi kotoran. Total koliform yang berada di dalam makanan atau minuman menunjukkan kemungkinan adanya mikroba yang bersifat enteropatogenik dan atau toksigenik yang berbahaya bagi kesehatan. Total koliform dibagi menjadi dua golongan ${ }^{4}$, yaitu koliform fekal, seperti $E$. coli yang berasal dari tinja manusia, hewan berdarah panas, dan koliform nonfekal, seperti Aerobacter dan Klebsiella yang bukan berasal dari tinja manusia, tetapi berasal dari hewan atau tanaman yang telah mati. Air olahan DAM harus bebas dari kandungan total koliform dan E. coli.

Hasil penelitian kualitas bakteriologi pelbagai sarana air minum menunjukkan air minum telah tercemar $E$. coli dan total koliform. Penelitian Tabor et al, ${ }^{5} \mathrm{di}$ Ethiopia terhadap kualitas air minum menunjukkan $45,7 \%$ tercemar koliform. Penelitian Eshcol et al, ${ }^{6}$ di India menunjukkan 36\% air minum rumah tangga tidak memenuhi syarat bakteriologi. Hasil penelitian Anwar, et al, ${ }^{7}$ menyatakan bahwa $37,2 \%$ air minum telah tercemar bakteriologi di Lahore. Hasil penelitian Admassu, et $a l, 8$ menunjukkan $50 \%$ air minum telah tercemar bakteri di Gondar. Penelitian Suprihatin dkk, ${ }^{9}$ di 10 kota besar di Indonesia menunjukkan 34\% sampel tidak memenuhi sedikitnya satu parameter kualitas air minum dan $16 \%$ sampel tercemar bakteri koliform. Hasil pemeriksaan Badan Pengawas Obat dan Makanan (BPOM) tahun 2003 terhadap mutu air produksi DAM di lima kota (95 depot) menyatakan bahwa 19\% tidak memenuhi syarat mikrobiologis (E. coli/total koliform/Salmonella). Hasil penelitian Rido Wandrivel dkk, 10 menunjukkan bahwa 55,5\% air isi ulang di Kecamatan Bungus Padang tidak memenuhi syarat bakteriologis. Hasil penelitian lain menunjukkan bahwa kualitas E. coli dan total koliform air baku masing-masing yang tidak memenuhi syarat adalah
3,5\% dan 6,9\%, sedangkan pada air olahan seluruhnya memenuhi syarat kesehatan. ${ }^{11} \mathrm{Hal}$ ini mengindikasikan bahwa kualitas air minum tidak selalu memenuhi syarat kesehatan setiap saat.

Kupang merupakan salah satu kota terbesar di Nusa Tenggara Timur (NTT) dengan jumlah penduduk 37.425 jiwa pada tahun 2013. Laju pertumbuhan penduduk $3,58 \%$. Peningkatan jumlah penduduk berdampak pada meningkatnya kebutuhan air minum. Jumlah DAM di Kota Kupang berkembang dengan pesat. Pada tahun 2010 jumlah DAM di Kota Kupang hanya 58 unit. ${ }^{12}$ Namun, berdasarkan data dinas kesehatan, pada tahun 2014 jumlah DAM di Kota Kupang telah meningkat menjadi 359 unit. Perkembangan ini disebabkan terbatasnya sumber air baku di Kota Kupang. Curah hujan diperkirakan hanya empat bulan setiap tahun sehingga memengaruhi ketersediaan air baku. Menurut Suprihatin, ${ }^{1}$ perkembangan DAM di suatu wilayah disebabkan persediaan air bersih semakin terbatas dan di sisi lain permintaan air minum mengalami peningkatan tajam. Mutu air minum berkualitas adalah hak setiap konsumen sekalipun harganya murah dan mudah terjangkau.

Hasil pemeriksaan Kantor Kesehatan Pelabuhan Kupang tahun 2013 terhadap tujuh sampel air minum isi ulang di Pelabuhan Kupang menunjukkan semuanya tercemar E. coli dan total koliform. Hasil pemeriksaan laboratorium Unit Pelaksana Teknik Dinas (UPTD) Laboratorium Kesehatan Provinsi NTT pada tahun 2013 di Kota Kupang menunjukkan bahwa 37,5\% DAM tidak memenuhi persyaratan mikrobiologis. Dari enam kecamatan di Kota Kupang, diperoleh data DAM tercemar tertinggi berada di Kecamatan Maulafa sebesar 20,83\%. Angka tersebut tidak memenuhi syarat sebagaimana ditetapkan dalam Keputusan Menteri Kesehatan No. 492/2010 yaitu 0/100 ml.

Adanya permasalahan kualitas air minum isi ulang produksi DAM mengindikasikan bahwa pengelolaan air minum isi ulang di Kecamatan Maulafa belum berjalan maksimal. Determinan yang dapat memengaruhi kualitas air minum isi ulang adalah sanitasi, kebersihan operator, kualitas alat desinfeksi, kecepatan aliran air, perilaku operator dan pengemasan air. Kurang memadainya pelbagai determinan tersebut dapat menimbulkan cemaran E. coli dan total koliform sehingga memengaruhi kesehatan masyarakat. Dari uraian dan permasalahan yang ada, maka rumusan permasalahan adalah bagaimana cemaran mikroba di Kecamatan Maulafa dan determinan apa saja yang memengaruhi cemaran E. coli dan total koliform pada air minum isi ulang.

Penelitian ini bertujuan menganalisis cemaran mikroba dan mengetahui determinan cemaran E.coli dan total koliform pada air minum isi ulang serta melakukan pemetaan cemaran mikroba di Kecamatan Maulafa. Hasil penelitian diharapkan dapat memberikan kontribusi ter- 
hadap peningkatan kualitas air minum isi ulang pada masa yang akan datang.

\section{Metode}

Desain penelitian ini adalah studi potong lintang. Populasi pada penelitian ini adalah seluruh DAM Kecamatan Maulafa sebanyak 51 depot pada periode Januari - Maret 2015. Pengambilan sampel menggunakan teknik total sampling karena jumlah populasi di bawah 100.

Data diperoleh dari data primer dan sekunder. Data primer meliputi karakteristik operator yang diperoleh dengan wawancara, kondisi sanitasi, kebersihan operator, kualitas desinfeksi, pengemasan air yang diperoleh dengan observasi, kecepatan aliran air, perilaku (pengetahuan, sikap dan tingkah laku) operator, letak DAM diperoleh dengan pengukuran, sedangkan cemaran mikroba yakni E. coli dan total koliform diperoleh melalui pemeriksaan laboratorium. Sampel diambil dari keran pengisian air minum isi ulang menggunakan botol steril secara aseptis serta mengenakan alat pelindung diri berupa masker dan sarung tangan, kemudian dikirim ke laboratorium yang terakreditasi. Sedangkan data sekunder meliputi jumlah DAM dan lokasi penelitian.

Instrumen yang digunakan dalam pengumpulan data adalah kuesioner, stop watch dan global positioning system (GPS). Hasil pemeriksaan sanitasi, kebersihan operator, kualitas desinfeksi, tingkah laku memenuhi syarat apabila nilai total skor $>70 \%$ dan tidak memenuhi syarat apabila nilai total skor $<70 \%$ berdasarkan standar Peraturan Menteri Kesehatan No. 43 tahun 2014. Hasil pengukuran pengetahuan dan sikap diperoleh berdasarkan jawaban responden setelah mengisi kuesioner, sedangkan hasil pemeriksaan kualitas air minum isi ulang tercemar jika ditemukan $E$. coli dan atau total koliform dan tidak tercemar jika tidak ditemukan $E$. coli dan total koliform. Jenis data dalam penelitian ini terdiri dari data kualitatif, yaitu sanitasi, kebersihan operator, kualitas desinfeksi, pengemasan, dan data kuantitatif yakni kecepatan aliran air dan perilaku operator. Selanjutnya, data dianalisis secara univariat, uji bivariat menggunakan regresi logistik sederhana untuk melihat ada tidaknya pengaruh variabel bebas dan terikat secara parsial, uji multivariat menggunakan uji regresi logistik berganda digunakan mengetahui ada tidaknya pengaruh sanitasi, kebersihan operator, kualitas desinfeksi, kecepatan aliran air, perilaku operator dan pengemasan terhadap cemaran mikroba secara simultan.

\section{Hasil}

Sebagian besar operator DAM berusia antara 20 - 29 tahun. Air minum tercemar mikroba terbanyak (38,46\%) ditemukan pada operator usia 20 - 29 tahun dan terendah $(11,53 \%)$ pada usia 30 - 39 tahun. Rerata usia operator adalah 35,16 + 12,07 SD tahun. Sebagian besar berpendidikan sekolah menengah atas (SMA) $(52,94 \%)$ dan terendah $(1,96 \%)$ tidak tamat sekolah dasar (SD). Air minum isi ulang tercemar mikroba terbanyak (100\%) ditemukan pada operator berpendidikan tidak tamat SD dan terendah $(44,44 \%)$ dengan tingkat pendidikan perguruan tinggi. Sebagian besar $(60,78 \%)$ masa kerja operator adalah satu sampai dua tahun dan terendah $(5,88 \%)>5$ tahun. Air minum isi ulang tercemar terbanyak $(51,61 \%)$ ditemukan pada operator dengan masa kerja 1 - 2 tahun dan terendah $(33,33 \%)$ dengan masa kerja $>5$ tahun. Jumlah operator sebanyak satu orang dan sebagian kecil pemilik DAM bekerja sebagai operator. Lama DAM beroperasi sebagian besar $(53,85 \%) \leq 1$ tahun, sedangkan sebagian kecil $(3,85 \%)$ telah beroperasi selama $\geq 5$ tahun. Air minum isi ulang tercemar tertinggi $(87,50 \%)$ ditemukan pada lama DAM $>5$ tahun dan terendah $(40 \%)$ pada lama DAM $<1$ tahun (Tabel 1).

Tabel 2 menggambarkan distribusi frekuensi sanitasi, kualitas desinfeksi, kebersihan operator, pengemasan air. Sanitasi DAM sebagian besar $(72,55 \%)$ memenuhi syarat, kualitas desinfeksi sebagian besar $(90,20 \%)$ memenuhi syarat, kebersihan operator sebagian besar $(64,71 \%)$ tidak memenuhi syarat dan kondisi pengemasan sebagian besar $(82,35 \%)$ memenuhi syarat.

Variabel lain yang diukur adalah kecepatan air dan

Tabel 1. Karakteristik Operator dan Lama DAM

\begin{tabular}{llll}
\hline $\begin{array}{l}\text { Karakteristik Operator } \\
\text { dan Lama DAM }\end{array}$ & Kategori & Frekuensi & $\%$ \\
\hline Usia & & & \\
& $20-29$ tahun & 9 & 37,25 \\
& $30-39$ tahun & 16 & 31,37 \\
& $40-49$ tahun & 8 & 15,69 \\
Tingkat pendidikan & $>50$ tahun & 8 & 15,69 \\
& Tidak tamat SD & 1 & 1,96 \\
& Tamat SD & 6 & 11,76 \\
& Tamat SMP & 8 & 15,69 \\
& Tamat SMA & 27 & 52,94 \\
Masa kerja & Tamat perguruan tinggi & 9 & 17,65 \\
& $<1$ tahun & 9 & 17,65 \\
& $1-2$ tahun & 31 & 60,78 \\
& $3-4$ tahun & 8 & 15,69 \\
Lama DAM & $>5$ tahun & 3 & 5,88 \\
& $\leq 1$ tahun & 27 & 53,85 \\
& 2 - 3 tahun & 10 & 19,23 \\
& 3 - 4 tahun & 12 & 23,08 \\
& $\geq 5$ tahun & 2 & 3,85 \\
\hline
\end{tabular}

Tabel 2. Distribusi Frekuensi Sanitasi, Kualitas Desinfeksi, Kebersihan Operator dan Pengemasan Air

\begin{tabular}{lcccc}
\hline \multirow{2}{*}{ Variabel } & \multicolumn{2}{c}{ Memenuhi Syarat } & \multicolumn{2}{c}{ Tidak Memenuhi Syarat } \\
\cline { 2 - 5 } & n & $\%$ & n & $\%$ \\
\hline Sanitasi & 37 & $72,55 \%$ & 14 & $27,45 \%$ \\
Kualitas desinfeksi & 46 & $90,20 \%$ & 5 & $9,80 \%$ \\
Kebersihan operator & 18 & $35,29 \%$ & 33 & $64,71 \%$ \\
Pengemasan air & 42 & $82,35 \%$ & 9 & $17,65 \%$ \\
\hline
\end{tabular}


perilaku operator. Pengukuran kecepatan air digunakan untuk mengetahui lama waktu pengisian galon (19 liter) dalam satuan menit. Hasil pengukuran diperoleh mean kecepatan air, yaitu 1,41 $\pm 0,566$ SD. Kecepatan air tertinggi adalah 3,4 menit dan terendah adalah 0,67 menit. Perilaku operator diukur dengan pengetahuan, sikap dan tingkah laku. Mean tingkat pengetahuan, sikap, dan tingkah laku operator berturut-turut adalah 10,49 $\pm 4,08$ $\mathrm{SD}, 17,02 \pm 1,72 \mathrm{SD}, 15,40 \pm 1,47 \mathrm{SD}$.

Tabel 3 menggambarkan cemaran mikroba DAM. Hasil pemeriksaan menunjukkan air minum isi ulang tercemar mikroba sebesar $51 \%$ dan tidak tercemar mikroba sebesar 49\%. Dari cemaran tersebut, diperoleh DAM tercemar E. coli sebesar 33,33\% dan total koliform sebesar $51 \%$. Distribusi cemaran mikroba tertinggi di Kecamatan Maulafa ditemukan di Kelurahan Sikumana, Oepura, dan Kolhua. Warna merah menandakan DAM telah tercemar dan warna biru menandakan DAM tidak tercemar (Gambar 1).

Tabel 4 menggambarkan hasil uji bivariat variabel bebas dan terikat. Uji bivariat digunakan untuk mengetahui

Tabel 3. Distribusi Cemaran Mikroba DAM

\begin{tabular}{lcl}
\hline Cemaran Mikroba & Frekuensi & $\%$ \\
\hline Tercemar & 26 & 51 \\
Tidak tercemar & 25 & 49 \\
\hline Total & $\mathbf{5 1}$ & $\mathbf{1 0 0}$ \\
\hline
\end{tabular}

pengaruh masing-masing variabel bebas dan terikat. Variabel bebas adalah sanitasi, kebersihan operator, kualitas desinfeksi, kecepatan aliran air, pengemasan, dan perilaku operator. Sedangkan variabel terikat adalah cemaran mikroba. Hasil uji menunjukkan enam variabel tidak berpengaruh terhadap cemaran mikroba, yaitu sanitasi, kebersihan operator, kualitas desinfeksi, kecepatan aliran air, pengemasan, dan tingkah laku. Sedangkan dua variabel berpengaruh adalah pengetahuan dan sikap. Hasil analisis statistik variabel pengetahuan diperoleh nilai odds ratio (OR) sebesar 1,235 artinya semakin tinggi tingkat pengetahuan, maka peluang air minum isi ulang tidak tercemar akan semakin meningkat sebesar 1,235 kali. Demikian halnya dengan variabel sikap (OR = $1,448)$, semakin tinggi sikap operator, maka peluang air minum isi ulang tidak tercemar sebesar 1,448 kali.

Tabel 5 menunjukkan hasil uji multivariat variabel bebas dan terikat. Uji multivariat digunakan untuk mengetahui pengaruh variabel bebas dan terikat secara simultan. Dari enam variabel kandidat (nilai $\mathrm{p}<0,25$ ) yang diuji pada $\alpha=5 \%$, terdapat tiga variabel dominan yang memengaruhi cemaran mikroba, yaitu pengetahuan, kebersihan operator, dan sanitasi. Persamaan regresi logistiknya adalah $Z=-1,941$; sanitasi $-1,589$; kebersihan operator $+0,263$; pengetahuan $-10,809$. Persamaan ini menggambarkan kebersihan dan sanitasi berpengaruh negatif terhadap cemaran mikroba, sedangkan pengetahuan berpengaruh positif terhadap cemaran mikroba.

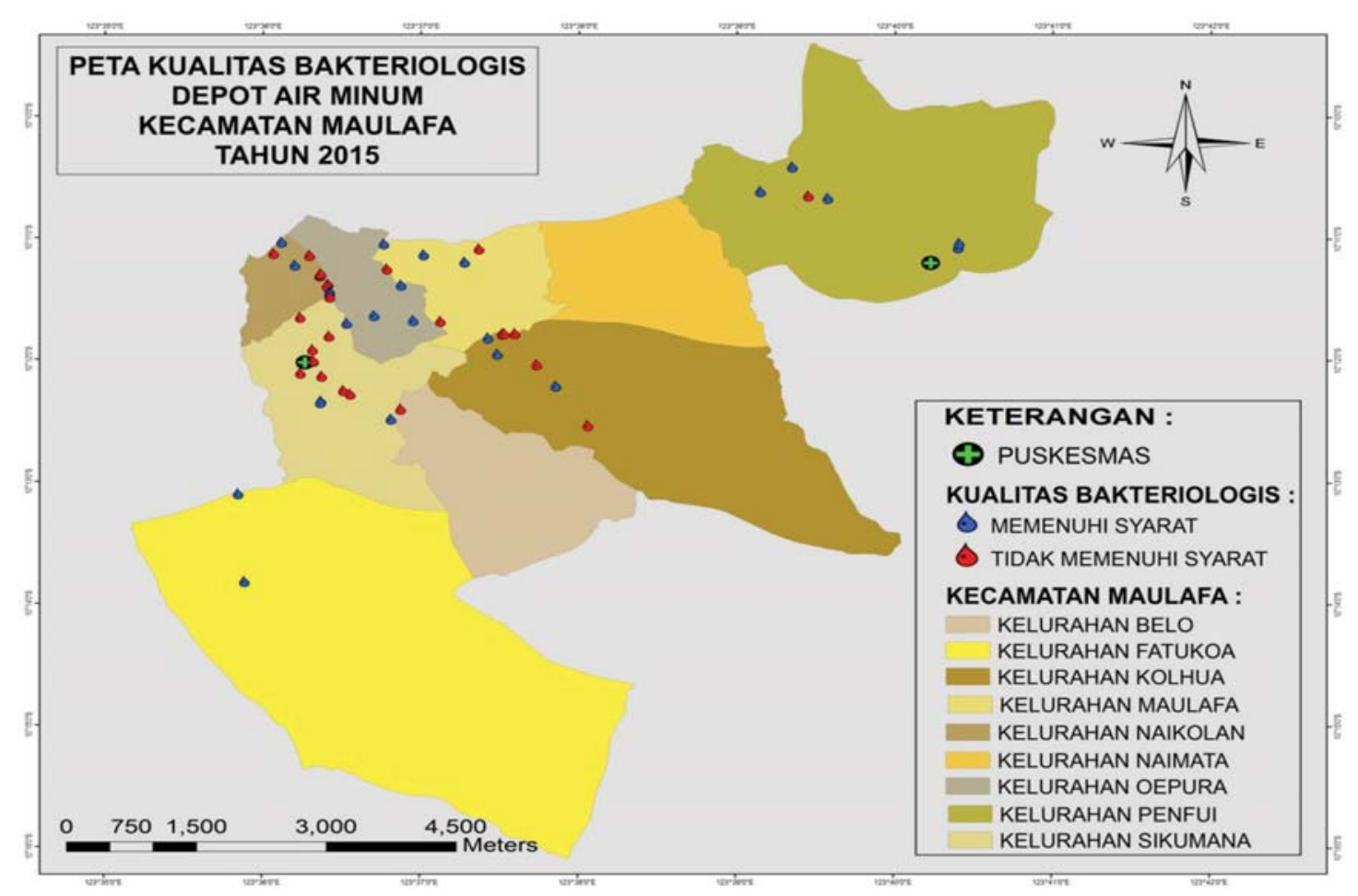

Gambar 1. Peta Cemaran Mikroba DAM 
Tabel 4. Hasil Analisis Bivariat

\begin{tabular}{lllll}
\hline Variabel & Kategori & Nilai $\mathbf{p}$ & OR & $\mathbf{R}^{\mathbf{2}}$ \\
\hline Sanitasi & & 0,185 & 0,423 & 0,047 \\
Higiene operator & & 0,184 & 0,454 & 0,047 \\
Kualitas desinfeksi & & 0,203 & 0,436 & 0,05 \\
Kecepatan aliran air & & 0,843 & 0,916 & 0,001 \\
Pengemasan & & 0,763 & 1,250 & 0,002 \\
Perilaku & Pengetahuan & 0,015 & 1,235 & 0,17 \\
& Sikap & 0,050 & 1,444 & 0,11 \\
& Tingkah laku & 0,072 & 1,448 & 0,08 \\
\hline
\end{tabular}

Tabel 5. Analisis Multivariat terhadap Cemaran Mikroba

\begin{tabular}{llllll}
\hline Variabel & B & Nilai $\mathbf{p}$ & OR & $\mathbf{9 5 \%} \mathbf{C I}$ & $\mathbf{R}^{\mathbf{2}}$ \\
\hline Sanitasi & $-1,941$ & 0,044 & 0,144 & $0,022-0,950$ & 0,455 \\
Kebersihan operator & $-1,589$ & 0,050 & 0,240 & $0,061-0,958$ & \\
Pengetahuan & 0,263 & 0,026 & 1,308 & $1,08-1,59$ & \\
Konstan & $-10,809$ & 0,047 & 0,00 & &
\end{tabular}

Jika kebersihan operator konstan, maka sanitasi memengaruhi cemaran mikroba sebesar -1,941 dan pengetahuan memengaruhi cemaran mikroba sebesar 0,263. Hasil uji diperoleh nilai OR berturut-turut untuk sanitasi, kebersihan adalah 0,144 dan 0,240 artinya, sanitasi dan kebersihan operator tidak memenuhi syarat memiliki risiko 0,144 kali dan 0,240 kali tercemar mikroba dibandingkan dengan sanitasi dan kebersihan operator yang memenuhi syarat. Pada variabel pengetahuan, diperoleh OR 1,308 yang artinya semakin tinggi tingkat pengetahuan, maka peluang air minum isi ulang tidak tercemar akan meningkat sebesar 1,308. Nilai $\mathrm{R}^{2}$ sebesar 45,5 menunjukkan variabel sanitasi, kebersihan operator, dan pengetahuan dapat menjelaskan $45,5 \%$ pengaruhnya terhadap cemaran mikroba sedangkan 54,5\% dipengaruhi oleh variabel lain.

\section{Pembahasan \\ Cemaran Mikroba}

Hasil pemeriksaan air minum isi ulang menunjukkan bahwa 51\% DAM telah tercemar mikroba. Air minum isi ulang telah tercemar Escherichia coli (E. coli) sebesar $33,33 \%$. Hal ini dapat dipastikan bahwa air tersebut telah tercemar kotoran hewan atau manusia pada tahap pengolahan. Di Kabupaten Bogor tahun 2007, hasil penelitian air minum isi ulang menyatakan 7,44\% DAM telah tercemar E. coli dan total koliform. ${ }^{11}$ Penelitian lain di Jakarta Selatan tahun 2008 menyatakan 15,38\% DAM telah tercemar bakteriologis. ${ }^{12}$ Di Kecamatan Bungus, hasil penelitian air minum isi ulang pada tahun 2012 menyatakan 55,6\% DAM kualitasnya tidak memenuhi persyaratan mikrobiologi. ${ }^{10}$ Hasil penelitian air minum isi ulang di Sukolilo tahun 2013 menyatakan $66,66 \%$ DAM telah tercemar total koliform ${ }^{13}$, sedangkan di Kabupaten Blora tahun 2013 menunjukkan 4\% air minum isi ulang telah terkontaminasi total ko- liform. ${ }^{14}$ Hasil penelitian air minum isi ulang di Manado tahun 2013 menyatakan bahwa semua air minum isi ulang telah tercemar total koliform dan telah tercemar $E$. coli sebesar $77,78 \% .{ }^{15}$ Hasil penelitian air minum isi ulang Lampung, tahun 2014 menyatakan 42\% DAM telah tercemar E. coli. ${ }^{16}$

Adanya cemaran ini dapat menimbulkan masalah kesehatan. Sebagian besar konsumen memilih air minum isi ulang karena harga murah dan terjangkau, namun mereka tidak menyadari sebagian DAM telah tercemar mikroba. Kurangnya informasi kualitas air minum isi ulang merupakan penghambat bagi konsumen memilih DAM berkualitas. Pemilik DAM harus dapat memberikan informasi kondisi peralatan, kebersihan operator, dan kualitas air minum isi ulang secara terbuka kepada konsumen. Informasi demikian harus tercatat dan dapat dibaca oleh setiap konsumen pada waktu pengisian air.

Usaha DAM dapat menggerakkan ekonomi masyarakat dan mengurangi pengangguran. Adanya DAM membantu masyarakat ekonomi rendah untuk mempermudah akses air minum. Namun, adanya masalah cemaran mikroba dapat berakibat turunnya kepercayaan masyarakat membeli air minum isi ulang karena dapat mengganggu kesehatannya. Pemilik DAM harus dapat menjaga kualitas air minum isi ulang agar bebas dari E. coli dan total koliform. Menurut Copeland et $a l,{ }^{17}$ cemaran air minum dapat disebabkan karena praktik penyimpanan air dan lamanya sirkulasi air baku DAM, yaitu $>3$ hari memengaruhi kandungan mikroba. ${ }^{18}$ Selain itu, menurut Yudo, dkk, ${ }^{19}$ meningkatkan kualitas air minum isi ulang perlu standarisasi sistem pemroses dan teknologi pengolahan. Konsumen diharapkan lebih selektif memilih dan membeli air minum isi ulang bukan hanya karena murah dan terjangkau. Konsumen dapat mengamati sanitasi DAM atau pekarangan, kebersihan dan kesehatan operator, indikator lampu penyinaran ultraviolet (UV), dan kualitas air minum isi ulang terlebih dahulu.

\section{Sanitasi Depot Air Minum dan Cemaran Mikroba}

Pemeriksaan sanitasi dilakukan terhadap lokasi DAM, bangunan, lantai, dinding, atap dan langit, ventilasi, fasilitas sanitasi dasar seperti jamban, saluran pembuangan air limbah, tempat sampah, tempat cuci tangan dan sabun, vektor maupun binatang pembawa penyakit seperti lalat, tikus dan kecoa. Hasil analisis multivariat menunjukkan sanitasi berpengaruh terhadap cemaran mikroba. Sanitasi tidak memenuhi syarat berisiko 0,14 kali tercemar mikroba dibandingkan dengan sanitasi memenuhi syarat $(\mathrm{OR}=0,14)$. Hasil penelitian ini sejalan dengan penelitian sebelumnya di Semarang pada tahun 2004 yang menyatakan terdapat hubungan sanitasi (nilai $\mathrm{p}=0,0001$ ) dengan kualitas bakteriologis. ${ }^{20} \mathrm{Hal}$ ini menjelaskan bahwa semakin baik kondisi sanitasi, maka se- 
makin baik pula kualitas bakteriologis air minum isi ulang. Namun, hasil penelitian ini tidak sejalan dengan penelitian sebelumnya yang menyatakan tidak terdapat hubungan antara sanitasi dengan jumlah koliform air minum isi ulang di Kabupaten Demak. ${ }^{21}$ Pada penelitian ini, sanitasi berkategori baik ditemukan 90,9\% air minum isi ulang memenuhi syarat dan pada sanitasi tidak baik ditemukan $62,5 \%$ kualitas bakteriologis tidak memenuhi syarat. Penelitian lain di Bogor menyatakan tidak terdapat hubungan (nilai $\mathrm{p}=0,944$ ) sanitasi dengan kontaminasi E. coli.22 Pada penelitian ini, rata-rata skor sanitasi untuk air minum isi ulang memenuhi syarat adalah 189,79 \pm 59,51 SD dan skor sanitasi untuk air minum isi ulang tidak memenuhi syarat adalah 187,55 \pm 37,75 SD.

Variabel sanitasi merupakan variabel confounding terhadap variabel kualitas desinfeksi, kebersihan, sikap, dan tingkah laku. Informasi ini menunjukkan bahwa cemaran mikroba sebagian besar dari kualitas desinfeksi tidak memenuhi syarat, kebersihan yang tidak memenuhi syarat, serta nilai sikap dan tingkah laku yang masih rendah. Sanitasi DAM dapat ditingkatkan melalui penyediaan fasilitas sanitasi dan pelatihan, penyuluhan kepada operator maupun pemilik. Pelatihan dan penyuluhan kebersihan sanitasi dapat meningkatkan praktik sanitasi sehingga dapat menurunkan cemaran mikroba. Menurut Chemulity et al, ${ }^{23}$ sanitasi lingkungan yang tidak memadai merupakan sumber potensi kontaminasi air minum dan perbaikan kualitas air minum dilakukan melalui upaya peningkatan sanitasi. ${ }^{24}$

\section{Kebersihan dan Cemaran Mikroba}

Hasil analisis multivariat menunjukkan kebersihan operator berpengaruh terhadap cemaran mikroba. Hasil penelitian ini sejalan dengan penelitian di Kabupaten Demak yang menyatakan terdapat hubungan (nilai $\mathrm{p}=$ $0,001)$ kebersihan dengan jumlah koliform air minum isi ulang. ${ }^{21}$ Dalam penelitian ini, diperoleh kebersihan kategori baik terdapat $88,2 \%$ air minum isi ulang memenuhi syarat dan semua $(100 \%)$ kebersihan dengan kategori tidak baik ditemukan air minum isi ulang tidak memenuhi syarat. Hasil ini menunjukkan semakin tinggi kualitas kebersihan, maka kualitas air minum isi ulang semakin baik. Namun, hasil penelitian ini tidak sejalan dengan penelitian di Bogor yang menyatakan tidak terdapat hubungan kebersihan dengan kontaminasi E. coli. Dalam penelitian ini, rata-rata skor kebersihan pada kualitas air minum isi ulang memenuhi syarat 52,82 \pm $35,38 \mathrm{SD}$, sedangkan rata-rata skor kebersihan pada kualitas air minum isi ulang tidak memenuhi syarat 43,33 $\pm 15,28$ SD. Hasil penelitian ini juga tidak sesuai dengan penelitian Asfawi, ${ }^{20}$ di Semarang yang menyatakan tidak terdapat hubungan (nilai $p=0,162$ ) kebersihan terhadap kualitas bakteriologis. Dalam penelitian ini, kualitas ke- bersihan pekerja baik diperoleh $87,5 \%$ kualitas air minum isi ulang memenuhi syarat, sedangkan kualitas kebersihan pekerja tidak baik diperoleh $76,2 \%$ air minum isi ulang memenuhi syarat.

Kebersihan operator sebagian besar tidak memenuhi syarat disebabkan operator tidak melakukan pemeriksaan kesehatan berkala dan tidak menggunakan pakaian seragam bersih dan rapih saat bekerja. Operator tampaknya tidak menyadari pentingnya melakukan pemeriksaan kesehatan dan menggunakan pakaian seragam sebagai upaya pencegahan penyebaran penyakit melalui air kepada konsumen.

Hasil uji statistik menunjukkan bahwa kebersihan operator merupakan variabel confounding terhadap variabel sanitasi dan pengetahuan. Hal ini menunjukkan sebagian besar cemaran mikroba terdapat pada operator yang nilai pengetahuannya rendah dan sanitasi yang tidak memenuhi syarat. Peningkatan kebersihan dapat dilakukan melalui pemeriksaan kesehatan secara berkala mininal dua kali setahun untuk skrining penyakit bawaan, menggunakan pakaian seragam saat bekerja, serta menjaga kebersihan diri. Pemilik DAM diharapkan dapat menyediakan seragam kerja dan menyediakan fasilitas sanitasi untuk mendukung kebersihan operator.

\section{Pengetahuan dan Cemaran Mikroba}

Hasil analisis multivariat menunjukkan pengetahuan operator berpengaruh terhadap cemaran mikroba. Persamaan regresi logistik sederhana menunjukkan $\mathrm{Z}=$ 0,211 , pengetahuan $-2,293$ artinya setiap kenaikan pengetahuan sebanyak satu satuan maka akan terjadi penurunan cemaran mikroba sebesar 2,293. Sebagian besar operator belum mengetahui maksud dan manfaat kebersihan sanitasi, syarat lokasi dan pekarangan, syarat pengangkutan dan penyimpanan air baku, fungsi alat desinfeksi, akibat mengonsumsi air tercemar, syarat operator, syarat kualitas air minum.

Hasil uji multivariat menunjukkan pengetahuan merupakan variabel confounding terhadap kualitas desinfeksi, sanitasi, kebersihan, dan tingkah laku operator. Peningkatan pengetahuan dapat dilakukan dengan melaksanakan kursus kebersihan sanitasi DAM dan pendidikan atau penyuluhan kesehatan kepada operator DAM diselenggarakan oleh dinas kesehatan kota dan puskesmas. Dinas perindustrian dan perdagangan pengeluarkan izin operasi DAM seharusnya disertai sertifikat kursus operator. Adanya sertifikat merupakan bukti telah mengikuti kursus kebersihan sanitasi yang diharapkan menambah pengetahuan dalam mempraktikkan nilai-nilai kesehatan di tempat kerjanya.

\section{Kualitas Desinfeksi dan Cemaran Mikroba}

Hasil analisis multivariat menujukkan tidak terdapat pengaruh kualitas desinfeksi terhadap cemaran mikroba. 
Hasil observasi terhadap kualitas desinfeksi 51 DAM menunjukkan 94,12\% memenuhi syarat. Namun, tingginya kualitas desinfeksi memenuhi syarat tidak diimbangi dengan kualitas air olahan. Hal ini dapat disebabkan karena daya kerja UV tidak maksimal apabila air keruh, kandungan kepadatan tinggi, jarak lampu dengan permukaan air, temperatur, dan jenis organisme. Hal ini tidak sejalan dengan penelitian di Kabupaten Tegal pada tahun 2012 yang menghubungkan kualitas desinfeksi dengan kualitas mikrobiologis. Dalam penelitian ini, nilai $\mathrm{OR}=9,25$ menunjukkan kualitas desinfeksi tidak memenuhi syarat berisiko 9,25 kali tercemar mikroba dibandingkan kualitas desinfeksi memenuhi syarat. ${ }^{25}$

Peningkatan kualitas air minum isi ulang dapat dilakukan dengan pemilihan kualitas air baku sehingga daya kerja alat desinfeksi bekerja dengan optimal. Dinas kesehatan kota diharapkan dapat memperketat pengawasan kualitas air baku.

\section{Sikap dan Tingkah Laku Operator dan Cemaran Mikroba}

Hasil analisis multivariat menunjukkan sikap dan tingkah laku tidak berpengaruh terhadap cemaran mikroba. Variabel sikap merupakan varibel confounding terhadap variabel kualitas desinfeksi. Informasi ini menunjukkan bahwa cemaran mikroba terbanyak ditemukan pada kualitas desinfeksi tidak memenuhi syarat dan nilai sikap rendah, sedangkan variabel tingkah laku merupakan variabel confounding terhadap variabel sanitasi dan kualitas desinfeksi. Sebagian besar cemaran mikroba terdapat pada nilai tingkah laku rendah, kondisi sanitasi dan kualitas desinfeksi yang tidak memenuhi syarat.

Sikap merupakan reaksi atau respon seseorang yang masih tertutup terhadap suatu stimulus atau objek. ${ }^{2}$ Sikap belum merupakan suatu tindakan atau aktivitas, tetapi merupakan predisposisi tindakan. Tingkatan sikap meliputi menerima, menanggapi, menghargai, bertanggungjawab. Tingkah laku kesehatan merupakan respons seseorang yang bersifat aktif terhadap stimulus yang berkaitan dengan sakit atau penyakit, pelayanan kesehatan, makanan, serta lingkungan. ${ }^{2}$ Dalam penelitian ini, sikap dan tingkah laku tidak berpengaruh terhadap cemaran mikroba. Hal ini dapat disebabkan karena data penelitian ini merupakan data kontinu dan data populasi homogen. Penelitian selanjutnya dapat menggunakan data kategori. Untuk data homogen, perlu dilakukan jenis studi ekologi membandingkan beberapa kelompok.

\section{Kecepatan Aliran Air dan Cemaran Mikroba}

Kecepatan aliran air berkaitan dengan waktu kontak antara air baku dengan sinar UV. Hasil pengukuran menunjukkan rata-rata kecepatan aliran air adalah 1,41+ $0,56 \mathrm{SD}$ menit. Hasil analisis bivariat menunjukkan kecepatan aliran air tidak berpengaruh terhadap cemaran mikroba. Hal ini dapat disebabkan pengukuran kecepatan aliran air dalam galon tidak dapat dilaksanakan pada semua DAM dalam penelitian ini. Pada saat penelitian, beberapa konsumen tidak sedang melakukan pengisian air minum isi ulang sehingga pengukuran dilakukan dengan cara mengisi air pada gelas ukur dalam satuan detik, kemudian dikonversi dalam satuan galon per menit. Pengukuran seperti ini dapat menimbulkan ketidaktepatan hasil pengukuran kecepatan aliran air bila dibandingkan dengan pengukuran dalam galon. Penelitian selanjutnya perlu melakukan pengukuran pada galon sambil menunggu kedatangan konsumen melakukan pengisian air minum isi ulang.

Semakin lama air baku kontak dengan alat desinfeksi, maka semakin tinggi kesempatan alat desinfektan menyinari air baku yang menyebabkan matinya mikroba. Menurut Hardajanto, ${ }^{23}$ waktu kontak antara air dengan sinar UV minimal empat detik, dan waktu kontak antara air dan ozon minimal empat menit. Kecepatan aliran air sangat berperan. Jika kecepatan aliran air lebih cepat dari waktu yang ditentukan, maka efektivitas UV sebagai pembasmi bakteri yang merugikan akan menurun.

\section{Pengemasan Air dan Cemaran Mikroba}

Hasil analisis bivariat menunjukkan tidak terdapat pengaruh pengemasan terhadap cemaran mikroba. Hasil ini sejalan dengan penelitian di Kabupaten Bogor pada tahun 2012 yang menyatakan tidak terdapat hubungan pengemasan air terhadap kualitas air minum isi ulang. ${ }^{22}$ Tidak terdapat pengaruh pengemasan terhadap cemaran mikroba dapat disebabkan karena data bersifat homogen. Penelitian selanjutnya perlu melakukan studi ekologi untuk melakukan pengukuran pada beberapa kelompok. Hasil observasi terhadap pengemasan air sebagian besar disebabkan tidak menutup alat pembersih galon dan operator tidak mencuci tangan sebelum pengemasan air minum isi ulang. Prioritas peningkatan pengemasan air minum isi ulang dilakukan dengan menempatkan alat penyikat galon pada ruang tertutup atau menutup sikat galon dan operator mencuci tangan dengan air mengalir dan sabun.

\section{Kesimpulan}

Hasil penelitian analisis cemaran mikroba dan determinan cemaran E. coli dan total koliform pada DAM dapat disimpulkan bahwa jumlah DAM dalam penelitian ini adalah 51. DAM telah tercemar mikroba sebesar 51\% dan $33,33 \%$ telah tercemar E. coli. Hasil analisis multivariat menunjukkan bahwa variabel yang paling dominan memengaruhi cemaran mikroba adalah pengetahuan operator, sanitasi DAM dan kebersihan operator. Sedangkan variabel tidak berpengaruh adalah kualitas desinfeksi, sikap operator, tingkah laku operator, pengemasan, dan kecepatan aliran air. 


\section{Saran}

Dinas Kesehatan Kota Kupang perlu menyelenggarakan pelatihan, kursus kebersihan sanitasi DAM kepada para operator dan pemilik DAM, melaksanakan peningkatan pengawasan dan pembinaan DAM secara berkala. Puskesmas diharapkan melakukan penyuluhan kepada operator DAM secara berkala. Dinas Perindustrian dan Perdagangan Kota Kupang perlu menambah persyaratan sertifikasi kebersihan sanitasi DAM untuk pemberian izin operasi DAM. Pemilik DAM perlu menyediakan pakaian seragam dan fasilitas sanitasi. Operator DAM perlu melakukan pemeriksaan kesehatan secara berkala, pencucian tangan dengan air mengalir menggunakan sabun, mengenakan seragam dan mengikuti kursus kebersihan dan sanitasi DAM. Masyarakat diharapkan lebih selektif dalam memilih air minum DAM yang akan dikonsumsi.

\section{Daftar Pustaka}

1. Suprihatin, Suparno O. Teknologi proses pengolahan air. Bogor: IPB Press; 2013.

2. Notoatmodjo S. Kesehatan masyarakat ilmu dan seni. Jakarta: Rineka Cipta; 2011.

3. Mukono. Prinsip dasar kesehatan lingkungan. Surabaya: Airlangga Universitas Press; 2011.

4. Entjang I. Ilmu kesehatan masyarakat. Bandung: Citra Aditya Bakti; 2000.

5. Tabor M, Kibret M, Abera B. Bacteriological and physicochemical quality of drinking water and hygiene sanitation practices of consumnes in Bahir Dar City, Ethiopia. Ethiophian Journal of Health Science. Mar 2011 [cited 2014 Oct 15]; 21 (1): 19-26. Avalaible from: http://www.ncbi.nlm.nih.gov/pmc/articles/PMC3275851/.

6. Eshcol J, Mahapatra P, Keshapagu. Is fecal contamination of drinking water after collection assosiated with household water handling and hygiene practice? A study of urban slum households in Hyderabad, India. Journal of Water and Health. 2009 [cited 2014 Oct 5]; 7 (1): 145-54. Avalaiable from: http://www.iwaponline.com/jwh/007/0145/ 070145.pdf.

7. Anwar MS, Lateef S, Siddiq GM. Bacteriological of drinking water in Lahore. Biomedica. 2010 [2014 Nov4]; 26: 66-9. Avalaible from: www.thebiomedicapk.com/articles/206.pdf.

8. Admassu M, Wubset M, Gelaw B. A survey of bacteriological quality of drinking water in North Gondar. Department of Laboratory Technology: 2004 [Cited 2014 Oct 12]. Avalaible from: http://ejhd.uib.no/ejhdv18no2/8survey.pdf.

9. Suprihatin. Sebagian air minum isi ulang tercemar bakteri coliform.Tim Penelitian Laboratorium Teknologi dan Manajemen lingkungan. Bogor: Institut Pertanian Bogor; 2013.

10. Wandrivel R, Suharti N, Lestari Y. Kualitas air minum yang diproduksi DAMIU di Kecamatan Bungus Padang berdasarkan persyaratan mikrobiologi. Jurnal Kesehatan Andalas. 2012; 129-33.

11. Pratiwi AW. Kualitas bakteriologis air minum isi ulang di wilayah Kota Bogor. Kesmas: Jurnal Kesehatan Masyarakat Nasional. 2007; 2 (2): 58 63.
12. Radji M, Oktavia H, Suryadi H. Pemeriksaan bakteriologis air minum isi ulang di beberapa depo air minum isi ulang di daerah Lenteng Agung dan Srengseng Sawah Jakarta Selatan. Majalah Ilmu Kefarmasian. 2009; 5 (2): 101-9.

13. Marpaung DM, Marsono DB. Uji kualitas AMIU di Kecamatan Sukolilo Surabaya ditinjau dari perilaku dan pemeliharaan alat. Jurnal Teknik Publikasi Ilmiah Online Mahasiswa ITS. 2013; 2 (2).

14. Natalia AL, Bintari HS, Mustikaningtyas D. Kajian kualitas bakteriologis air minum isi ulang di Kabupaten Blora. Unnes Journal of Life Science. 2004; 3(1).

15. Bambang AG, Fatimawali, Kojong NS. Analisis cemaran bakteri coliform dan identifikasi Escherichia coli pada air isi ulang dari depot di Kota Manado. Jurnal Ilmiah Farmasi. 2014; 3 (3): 325-34.

16. Apriliana E, Ramadhian MR, Gapila M. Backteriological quality of refill depot water at refill drinking water depot in Bandar Lampung. Jurnal Kedokteran Universitas Lampung [online]. 2014 [diakses tanggal 5 Mei 2015]; 4 (7); 142-6. Diunduh dari: http://download.Portal garuda.org/article.

17. Copeland CC, Beers BB, Thompson MR, Fitzgerald RP, Barrett LJ, Sevilleja JE, et al. Faecal contamination of drinking water in a Brazilian shanty town: importance of household storage and new human faecal marker testing. Journal of Water and Health. 2009: 7 (2): 324-31.

18. Abdilanov D, Hasan D, Marsaulina I. Penyelenggaraan hygiene sanitasi dan pemeriksaan kualitas air minum pada depot air minum isi ulang di Kota Padang tahun 2012. Jurnal Kesehatan Lingkungan dan Kesehatan Kerja. 2013 [diakses tanggal 8 Oktober 2015]: 2. Diunduh dari http://id.portalgaruda.org/? ref=browse\&mod= viewarticle \&article $=110056$

19. Yudo S, Rahardjo PN. Evaluasi teknologi air minum isi ulang di DKI Jakarta. Jurnal Akuakultur Indonesia. 2005 [diakses tanggal 5 Mei 2015]; 1 (3). Diunduh dari: http://ejurnal.bppt.go.id/ index.php/JAI/article/view/48/47.

20. Asfawi S. Analisis faktor yang berhubungan dengan kualitas bakteriologis air minum isi ulang pada tingkat produsen di Kota Semarang [tesis]. Semarang: Universitas Diponegoro; 2004.

21. Mirza MN. Hubungan antara hygiene sanitasi dengan jumlah coliform air minum pada depot air minum isi ulang (DAMIU) di Kabupaten Demak. Kemas. 2013; 67-73.

22. Prihatini. Kualitas air isi ulang pada depot air minum di wilayah Kabupaten Bogor [skripsi]. Depok: Universitas Indonesia; 2009

23. Chemulity JK, Gatura PB, Kyule MM, Njeruh MM. Bacteriological qualities of indoor and out-door drinking water in Kibera sub-location in Nairobi, Kenya. East African Medical Journal. 2002 [cited 2015 Jan 08]; 79 (5): 271-3. Avalaible from: http://www.ajol.info/index. php/eamj/article/view/8868/1821

24. Levy K, Nelson KL, Hubbard A, Eisenberg JNS. Following the water: A controlled study of drinking water storage in Northern Coastal Ecuador. Environmental Health Perspectives. 2011 [cited 2014 Dec 5]; 111 (11): 1533-40. Avalaible from: http://ehp.niehs.nih.gov/wp-content/uploads/116/11/ehp.11296.pdf

25. Rahayu CR, Setiani O, Nurjazuli. Faktor resiko pencemaran mikrobiologi pada Air Minum Isi Ulang di Kabupaten Tegal. Jurnal Kesehatan Lingkungan Indonesia. 2013; 12 (1). 